\title{
Delineation of Wellhead Protection Areas: Methodology and Application
}

\author{
Eman R. Nofal \\ Researcher (Civil Engineer), National Water Research Center, Delta Barrage, Egypt
}

\begin{abstract}
About $97 \%$ of global fresh water is sourced from Groundwater, positioning it as an important, and sometimes the sole, source of drinking-water in many parts of the world. Sustainable Development Goals, Goal No. 6, calls to foster all efforts to ensure access to water and sanitation for all. Nevertheless, with groundwater providing nearly half the world population with drinking water, the responsibly of sustaining this resource is a priority to all. Pumping wells can sometimes, if not carefully protected, be an instant source of pollution to the groundwater. Wellhead protection areas (WHPAs) serve the purpose of protecting the quality of groundwater by means of restrictions imposed on land use activities within the WHPA. Many approaches are being used to delineate WHPAs all over the world. The study used the numerical groundwater flow modeling with particle tracking codes approach, as it allows full interaction of hydrogeological, land-use, PCS, and different extraction rates in delineating the WHPA. The study area is a drinking water plant, located in Menofia Governorate and belongs to the Nile Delta aquifer. The study used 50-day isochron horizontal travel distance for the three pumping wells, located in the drinking water plant. The WHPA radius was determined for wells and the resulted radii range from $37 \mathrm{~m}$ to $54.5 \mathrm{~m}$. Keywords:Wellhead protection area, groundwater protection, contaminant transport, MT3D, groundwater modelling
\end{abstract}

DOI: $10.7176 / \mathrm{CER} / 13-4-04$

Publication date: June $30^{\text {th }} 2021$

\section{Introduction:}

Safe and sustainable drinking water is among the essential human needs that is vital for public health and economic development. Potable water is essential for almost all activities in any community from municipal uses to food industries and agriculture post productions. Groundwater provides a sustainable safe source of water supply and enables communities to develop and exist in areas with no accessibility to rivers or lakes. With the increased population and development activities that result in increased pollution threads, more caution actions have to be considered in protecting the groundwater (NGWA, 2017). Groundwater exists beneath the surface in soil and rocks, and forms underground reservoir known as aquifers. About $97 \%$ of global freshwater is from groundwater and positioned as an important, and sometimes the sole, source of drinking-water in many parts of the world. Groundwater provides nearly half of the world's drinking water, either supplied to populations via public or private water systems (Smith et al., 2016). However, the reason behind the dependency on groundwater is because it is generally more sustainable in quality and quantity, better microbiological quality and less prone to pollution than surface waters.

Generally, groundwater requires no or minor treatment to be adjusted for drinking water guidelines, whereas surface waters often need treatment. In many parts of the world, groundwater is being distributed without treatment. Therefore, it is highly important to protect the groundwater quality; to preserve public health (WHO, 2006). Moreover, aquifers are often naturally protected by overlain soil layers, which acts as a filter media for percolated water and, thus remove almost all suspended particles, microorganisms and other chemical constituents. Inevitably, groundwater is considered a reliable source of adequate safe drinking water.

Wellhead protection areas (WHPAs) aim at maintaining the quality and quantity of abstracted groundwater from any well used in drinking purposes, by imposing restrictions on land-use activities within the WHPA. WHPAs is defined as the surface and subsurface surrounding areas to any groundwater well or wellfield, used for supplying drinking water, where contaminants can flow with natural of radial groundwater flow to the well screens. The abstraction process of any well within an aquifer leads to changes in the natural flow of groundwater. WHPAs can also be defined as the dynamic watersheds that accumulate discharged water from any well, and consequently potential contaminates, under certain abstraction rates. Most industrialized countries developed guidelines for WHPA delineation started by U.S. Environmental Protection Agency (EPA) in 1987. WHPAs are generally delineated by determining the well capture zone, wherein water is extracted from its pores, under certain extraction rates, to be withdrawn from the well screens; accounting also the travel time of water to reach the well screens (Sousa et. al, 2013).

WHPAs are being delineated by several methods. The US EPA adapted several methods and approaches for WHPA delineation. These methods are (EPA, 1997):

- arbitrary fixed radius

- calculated fixed radius 
- $\quad$ simplified variable shapes

- flow system mapping with uniform flow equation

- analytical flow/particle-tracking tools

- $\quad$ numerical flow/transport models

- $\quad$ hydrogeologic and vulnerability mapping

Accurate delineation of WHPAs is a complicated task, as it requires many pre-delineation investigations and data collection; includes land-use survey, hydrogeological survey, existing wells, potential contaminant sources, and recharge rates. Accuracy of the delineation process depends on the available data, complexity of the area, and requirement of the WHP program. Table 1 shows WHPA delineation methods and the corresponding data needed. The approach differs from degree of sophistication, court defensibility, and cost (Fadlelmawla and Dawoud, 2006).

Looking thoroughly into the various WHPA delineation methods, it could easily be concluded that the numerical flow/transport models are the most comprehensive method; as this method considers all the parameters governing the flow/transport of groundwater. The numerical modeling approach involves all the groundwater flow/transport parameters to successfully simulation the concerned area. These parameters are hydraulic conductivity, vertical leakage, well pumping rate, porosity, aquifer thickness, recharge rate, hydrologic boundaries, and aquifer geometries.

WHPA delineation methods vary in reliability as well as cost. The numerical groundwater flow/transport model method is considered the highest in costs, yet it also holds the highest reliability among the different methods. The accuracy of the delineation is directly relying on the validity of the conceptual model used simulate the aquifer system; which is also dependent on the accuracy and amount of data available for the delineation process. Nevertheless, the geometry of the delineated protection zone is also dependent on the delineation method used. Moreover, Minnes and Simpson, 2020, highlighted the importance, of not only, setting legislative tools for WHPAs but also raining the awareness of the protection measures taken within these areas between private wells owners. This study will present WHPA delineation method for a groundwater drinking well in the Nile Delta using numerical groundwater flow/transport model method.

Table 1: WHPA delineation methods and the corresponding data needed

\begin{tabular}{|c|c|c|c|c|c|c|c|c|}
\hline Method of delineation & $\boldsymbol{K}$ & $Q$ & $n$ & $I$ & $\boldsymbol{B}$ & \begin{tabular}{l|l}
$R$ & $\begin{array}{l}\text { Hydrogeological } \\
\text { boundary }\end{array}$
\end{tabular} & COST & RELIABILITY \\
\hline Arbitrary fixed radius & \multicolumn{6}{|c|}{$\begin{array}{l}\text { It is not scientifically based, but rather } \\
\text { determined based upon } \\
\text { hydrogeological knowledge. }\end{array}$} & lowest & least \\
\hline Calculated fixed radius & \multirow[b]{2}{*}{$\checkmark$} & \multicolumn{2}{|c|}{$\checkmark \checkmark \checkmark$} & & $\checkmark$ & & \multirow{2}{*}{$\uparrow$} & \multirow[t]{2}{*}{ A } \\
\hline Simplified variable shape & & $\checkmark$ & $\checkmark$ & $\checkmark$ & $\checkmark$ & & & \\
\hline $\begin{array}{l}\text { Analytical Hydrogeological } \\
\text { models }\end{array}$ & & $\checkmark$ & & & & $\checkmark$ & \multirow[b]{3}{*}{ highest } & \multirow[b]{3}{*}{ Most } \\
\hline $\begin{array}{l}\text { Hydrogeological and } \\
\text { vulnerability mapping }\end{array}$ & \multicolumn{6}{|c|}{$\begin{array}{l}\text { Based upon Geologic, soil, land use, and water } \\
\text { table maps }\end{array}$} & & \\
\hline $\begin{array}{l}\text { Numerical groundwater } \\
\text { flow models with particle } \\
\text { tracking routines }\end{array}$ & $\checkmark$ & $\checkmark$ & $\checkmark$ & $\checkmark$ & $\checkmark$ & 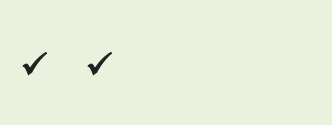 & & \\
\hline
\end{tabular}

$K$ : hydraulic conductivity, $Q$ : pumping rates, $n$ : porosity, I: hydraulic gradient, $B$ : aquifer thickness, and $R$ : recharge

\section{Materials and Methods}

\subsection{General approach}

Numerical groundwater/solute transport modeling is used as the applied approach in delineation of WHPA for drinking wells in this study. In order to successfully develop a numerical model to fulfill the objective of delineation of WHPA, certain data needs to be collected and analyzed. The data collection phase includes wells inventory, ground levels, lithology of wells, and hydrogeological data for groundwater aquifer. Wells inventory is crucial in determining the existing extraction rates. Large extraction rates highly influence the movement of pollutants as it enhances its mixing with the groundwater. Moreover, pumping tests analysis for the production wells is performed, in order to determine the hydraulic parameters of the aquifer (transmissivity and storativity). Vulnerability maps are prepared to locate the highly vulnerable areas to pollution. Groundwater Vulnerability is based on the natural geologic and hydrogeologic status of the area, and the degree of ease on which contaminants can move to reach the groundwater and consequently contaminate it. Groundwater vulnerability maps are prepared based on the subsoil layers; types and thicknesses of these layers highly influence the groundwater vulnerability at any area. Groundwater is highly vulnerable at areas where the subsoils are thin or absent, presence of karstic 
limestone in the area, and where the surface water in connected directly with the shallow groundwater. The Groundwater Vulnerability Maps presents the degree of groundwater vulnerability to a pollutant discharged at ground surface according to the geological, hydrogeological, and soil characteristics within the concerned area.

Potential contamination sources (PCSs) inventory investigates the establishments within the concerned area that could possibly produce and contaminate the drinking water. Moreover, PCSs are often associated with hazardous substances produced from existing establishments or land-use activities. Hazards may be chemical, biological, or radiological in nature. PCS in the similar study area vary from Industrial activities, contaminated surface waterways, septic tanks, agriculture activities and landfills.

After collecting and analyzing all the required data, three-dimensions groundwater and solute transport model is being built-up and utilized to determine the WHPA for the drinking wells.

\subsection{Physical and hydrogeological description of the study area}

The study area is located in Samadoun village, Ashmoun district, Menofia Governorate. A drinking water plant is located in the village to provide the villagers with their water. The water drinking plant depends on a pumping well as the source of fresh water in the village. The village lies between $30^{\circ} 21^{\prime}$ and $30^{\circ} 19^{\prime}$ in the north direction and $30^{\circ} 56^{\prime}$ and $30^{\circ} 58^{\prime}$ in the east direction. Most of the villagers rely on agriculture for living. There is no industrial activity in the village. The area is provided with surface water system to serve the agriculture activities (canals and drains). It is also considered as part of the traditionally cultivated area. The village is not served with sanitary network, however, instead it relies on uninsulated septic tanks to get rid the wastewater. Figure (1) shows satellite image for the study area.

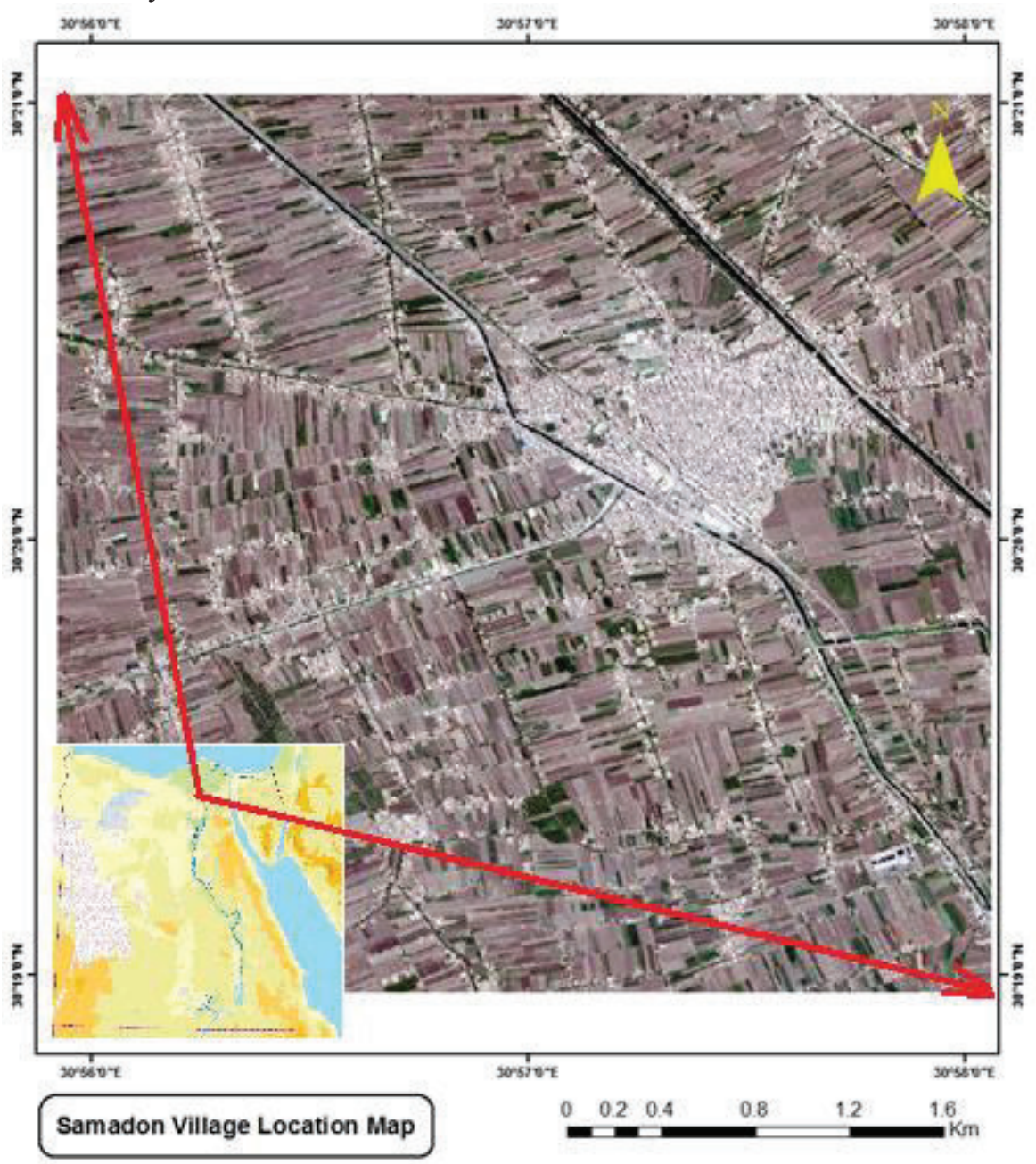

Figure 1. Satellite image for the study area

The study area is commonly flat; the area occupies a part of the young alluvial (fluviatile) plain, where the land surface has been prepared to provide a suitable surface for irrigation. The lateral and longitudinal slopes are very gentle all over area. The topography varies between 12 and 14 meters above mean sea level (obtained from SRTM data - set with $30 \mathrm{~m}$ resolution) and underlain by Holocene sandy silt and clay. Hydrogeological data and knowledge were obtained from the Hydrogeological Map of Egypt, Nile Delta (1992) at a scale of 1:500,000 
(RIGW, 1992). The existing aquifer related to the main Nile Delta, it is considered as a highly productive aquifer and consists of graded and gravel with clay intercalations belongs to Pleistocene age. The thickness of the Pleistocene deposits varies between 150-300m; Quaternary deposits cover the study area. These deposits represented by Holocene silty and clay deposits with a thickness vary between 10-15 m. The aquifer is underlain by thick Pliocene clay.

The Nile aquifer system in the Nile Delta is a huge groundwater reservoir extending to cover the entire Nile Delta region. The strata of hydrogeological importance belong essentially to the Quaternary (about one million years ago). The hydrogeological units of interest in studying the Nile Delta aquifer are as follows: i. Top unit of Holocene clay aquitard; ii. Quaternary and late Tertiary gravel and sands unit (aquifer); and iii. Basal unit of Pliocene clay aquiclude. The average horizontal hydraulic conductivity of the semi-pervious top layer is 0.25 $\mathrm{m}$ /day; while the magnitude of the hydraulic conductivity of the semi-pervious layer to vertical flow ranges from $0.01 \mathrm{~m} /$ day to $0.001 \mathrm{~m} /$ day in the south and north, respectively. The average aquifer hydraulic conductivity is about $75 \mathrm{~m} /$ day. The porosity of the sediments is $25 \%$ to $30 \%$. The average piezometric head varies between $10-12 \mathrm{~m}$ (above mean sea level). The groundwater flow direction is from the south to the north. The groundwater salinity is less than $500 \mathrm{ppm}$. The Nile Delta aquifer in the flood plain is continuously recharged by irrigation water in the southern and central portions. Because of this, the aquifer acts as storage reservoir and can be used accordingly. Recharge of groundwater is taking place in the Nile Delta area by three processes: Infiltration of rainfall water; Infiltration and downward leakage of excess surface irrigation water (originating from the river Nile) and leakage from canals; and Inter-aquifer flow of groundwater.

Recharge by rainfall takes place only during the winter months and has no significant effect on the Nile Delta aquifer due to the very small rainfall rates and the thick Holocene top silt and clay layer. The main recharge of the aquifer occurs through seepage from surface water, especially from irrigation canals and by downward percolation of subsurface drainage water in the traditionally cultivated lowlands. In the central and southern portions of the flood plain, the downward leakage towards the aquifer ranges between 0.25 and $0.8 \mathrm{~mm} /$ day, depending on the soil type, irrigation and drainage practices.

\subsection{Potential contaminant sources}

Most concern over groundwater contamination has centered on pollution associated with human activities. Laws, 2017, concluded that Human groundwater contamination can be directly related to waste disposal such as private sewage disposal systems, land disposal of solid waste, municipal wastewater, wastewater impoundments, land spreading of sludge, brine disposal from the petroleum industry, mine wastes, deep-well disposal of liquid wastes, animal feedlot wastes, and radioactive wastes. Also, groundwater contamination can occur by indirectly human caused waste disposal such as accidents, certain agricultural activities, mining, highway deicing, acid rain, improper well construction and maintenance, and road salt. Sources of Contamination are either Point or Nonpoint sources. Point sources of pollution are usually easy to inventory because they are visible and discrete; nonpoint sources are diffuse and often hard to trace to their sources. Another characteristic of nonpoint source pollution is that rules and regulations are usually not adequate to control it. Since many of these types of potential sources are unregulated, your effort should be focused on locating and inventorying them so effective control measures can be planned (Dressing el al., 2016). After investigating the concerned study area, the most threating contaminant sources were summarized to: Surface water ways and uninsulated septic tanks (Figure 2). 


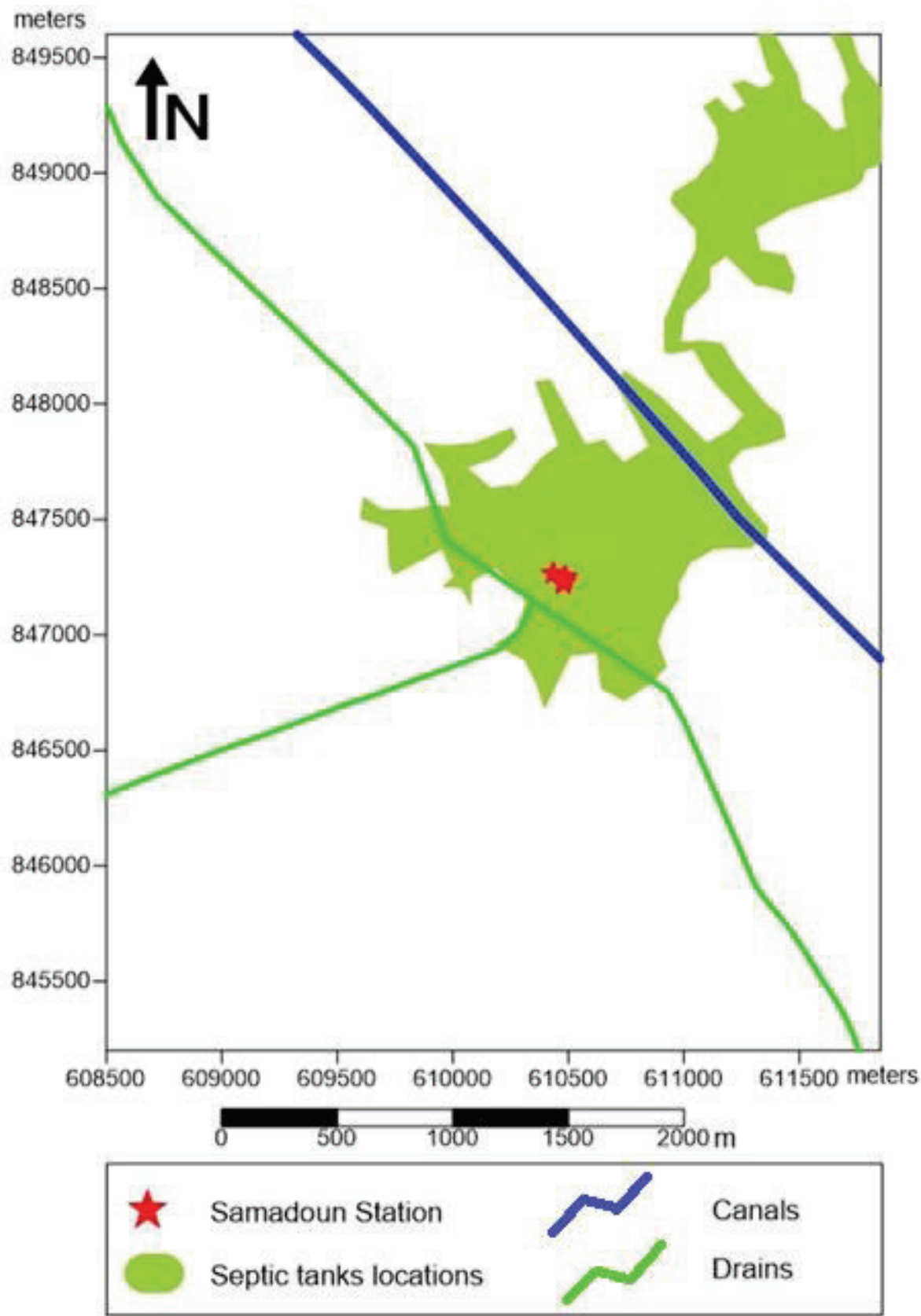

Figure 2. Schematic map for potential contaminant sources in the study area

\subsection{Numerical groundwater solute transport model}

MODFlow and MODPATH codes were chosen to simulate the study area within the Visual MODFlow Pro. V. 4.6 interface. The simulation was conducted in a three- dimensional approach, including advection of pollutants in the groundwater system in the study area. The simulated area is $14 \mathrm{~km}^{2}$ with $4.4 \mathrm{~km}$ in the north-south direction and $3.3 \mathrm{~km}$ in the east-west direction. The grid is divided into three layers according to the different hydrogeological characteristics.

The three-dimensional grid was constructed by generating four digitized surfaces. The digitized surfaces are topographic ground surface, base of top clay layer, piezometric heads, and base of aquifer, as shown in Figure (3). 


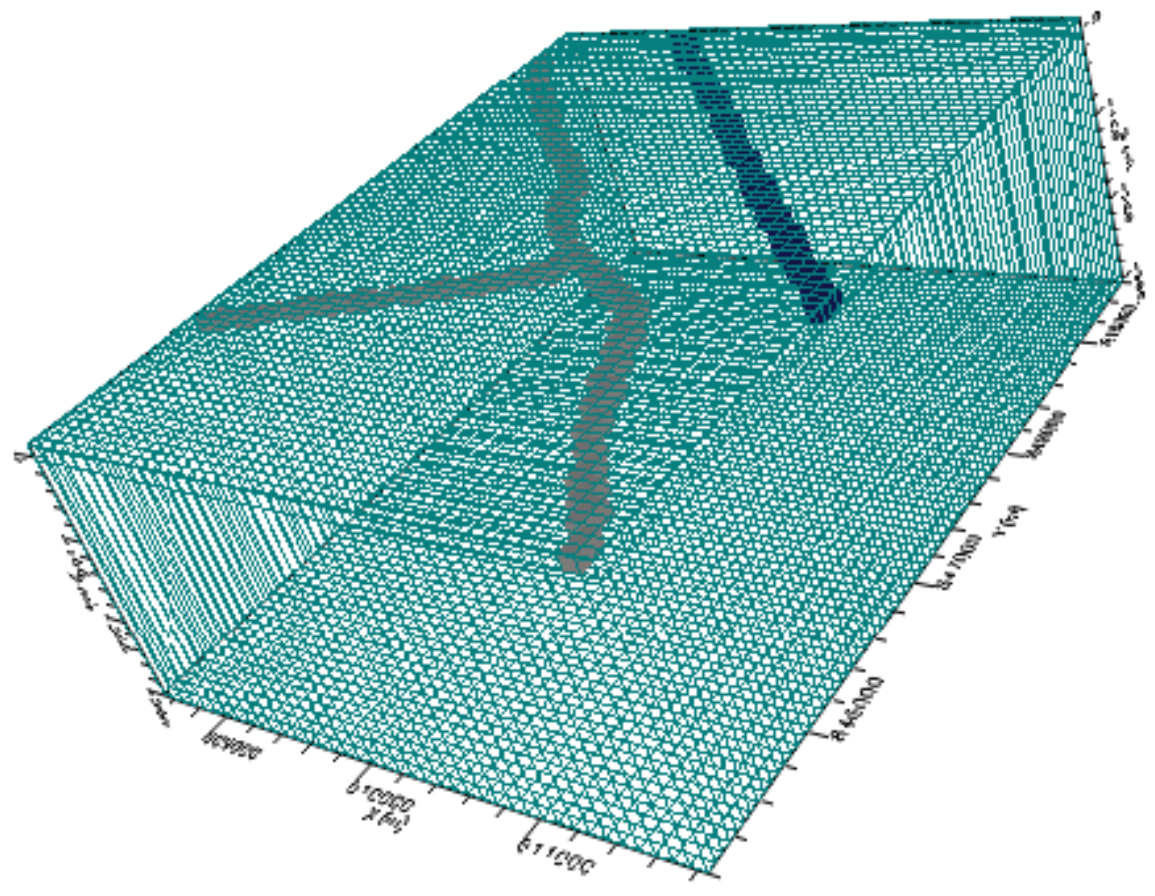

Figure 3. Three-dimensional grid for the simulated model

Flow boundary conditions of the study area are described as: a specified head in the North and South, noflow in the Western and Eastern boundary. Also, the canal and drains are included in the boundary conditions. These boundary conditions were determined according to the ground and surface water flow in the study area. To simulate the transport of potential pollutants, particles were released in the locations of the potential pollutants. The flow model is calibrated against the available average annual groundwater heads from the observation wells. The calibration process is done through several trials by adjusting the hydraulic conductivity and recharge rate. Results were found to be comparable with the average annual observed heads within acceptable difference.

\subsection{Delineating of WHPA}

Delineation of WHPA can be conducted through different approaches; either by analytical and numerical models or according to a specific guideline. WHPA can be defined, as the innermost area around the production drinking well that requires the highest level of protection, and is considered the highest prone to contaminant transport. WHPA is preferably to be owned and controlled by the groundwater extractor. This area has to be prohibited for any activities to avoid any possible contaminant transport from that area to the water source either directly through the well or via adjacent ground. Maintenance zone for the well inside the WHPA has to have concrete floor to prevent infiltration of fuel, oils, and chemicals matters used for operation and maintenance of the production well. Fencing of the WHPA is also required to prevent animals and unauthorized humans from entering this zone to protect it from destruction and contamination. Determination of WHPA is necessarily rather arbitrary and dependent to some degree on the nature of local geological formations.

According to the potential contaminant sources in most of the prone area in Egypt, microbiological protection area has to be considered in delineating the WHPA. It is highly important to prevent groundwater contamination with pathogenic bacteria, viruses, and parasites. The pathogens can easily reach the shallow groundwaters from contaminated surface watercourses, drains, septic tanks, and various other routes (Foster et al., 2007). Wells are considered the most prone mean of contaminant transport to the shallow aquifers specifically this type of contamination. As, contamination via the aquifer formation route is protected naturally by the attenuation capacity of the vadose zone and the semi-confining beds.

WHPA is calculated according to the distance taken by a particle to move horizontally in a saturated aquifer for a specified time interval. WHPA is used to protect drinking wells against potential contamination activities such as bacteria, parasites, and viruses coming from wastewater ways and landuse activities. The time used to calculate WHPA differs from country to country, ranging from 10 to 400 days.

Published data (Foster et al., 2007) suggests that the distance travelled horizontally by a contaminant in the saturated aquifer is depended on the groundwater velocity. According to the reported waterborne contamination outbreak incidents, the maximum distance travelled by the pathogenic pollution was 20 days, although, pathogens are known to survive in the subsurface saturates zone for 400 days.

Accordingly, 50 day isochron was chosen as a realistic time interval to define the WHPA, which agrees with 
current practices applied in many countries. this protection zone considered among the highest priorities in ensuring the public health. Moreover, as the delineated 50 day isochorn is often not large in terms of size, therefore, it is easily achieved and enforced for implementation. The 50-day isochron WPHA approach has been selected as the used delineation approach in this study.

After the calibration process, the MODPATH engine is run to track the pollutant particles within the groundwater flow. MODPATH is a post-processing particle tracking package that calculates three-dimensional flow path based on MODFLOW steady or un steady state groundwater flow output through adapting a semianalytic particle tracking scheme. The computed flow paths of any particle is tracked from one cell to another until reaching an internal sink/source, a boundary, or reaching other termination criterion (Pollock, 2012). MODPATH computes paths for imaginary "particles" through the simulated groundwater flow system and calculates the time it takes to travel through the system or terminates.

The current extraction rates from all the pumping wells inventoried in the study area was activated in the numerical calibrated model. The extraction enhances the groundwater flow and increases its velocity; which consequently accelerate the particles movement. After applying the current extraction rates in the study area, particle tracking is being simulated.

The simulated pathlines shows the migration of PCS, which are the surface water ways (canal and drains). The imaginary pathlines shows that particles of PCS can travel into the direction of the drinking water well as shown in Figure (4). Looking deeply into the simulated pathlines, it shows that the PCS pathlines can reach up to $90 \mathrm{~m}$ depth into the aquifer as shown in Figure (5).

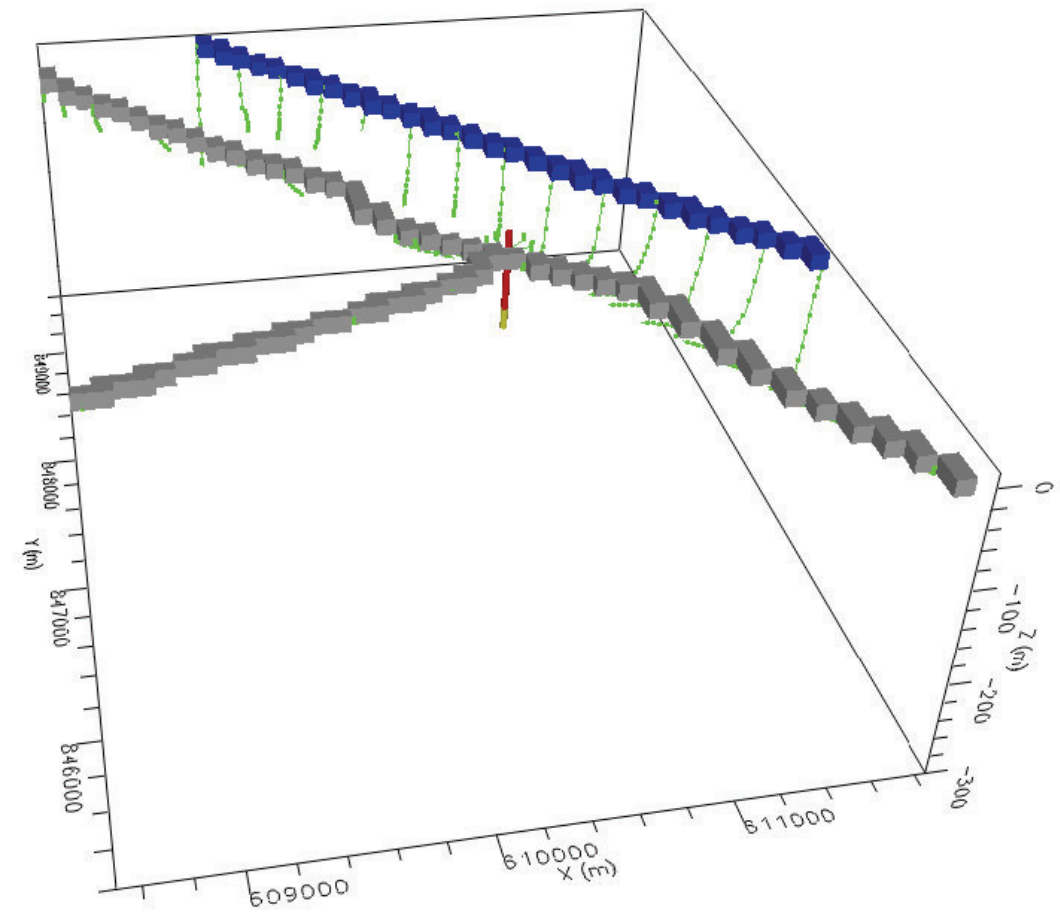

Figure 4. Simulated imaginary pathlines from PCS traveling towards the drinking well 


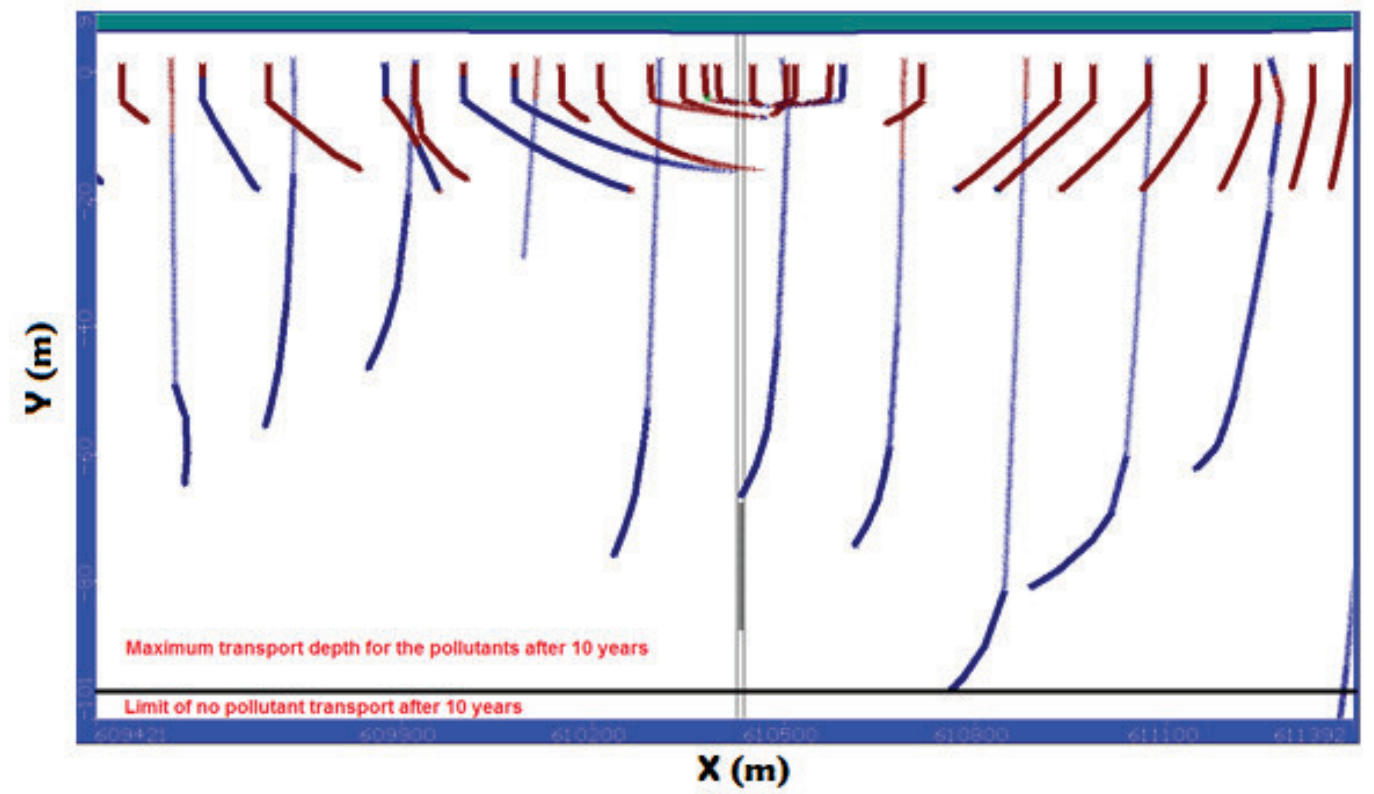

Figure 5. Cross section at the drinking well and showing the migration of simulated imaginary pathlines from PCS

\section{Results and Discussions}

Since WHPA is calculated according to the distance taken for a particle to move horizontally in a saturated zone aquifer, for a specified time interval, specifically, the 50-day isochron WPHA approach. The simulated imaginary pathlines from PCS traveling towards the drinking well has been determined along with its flowtime. Figure (6) shows the pathines into the pumping wells with flowtime ticks. 50-day isochron WPHA delineation is performed for all the drinking wells. The WHPA radius for each pumping well was delineated, reflecting the extraction rates and the hydrogeological conditions. The WHPA radius for the three pumping wells were superimposed and the combined WHPA is delineated, as shown in Figure (7). The WHPA radius was determined for the three wells and the radius ranges from $37 \mathrm{~m}$ to $54.5 \mathrm{~m}$.

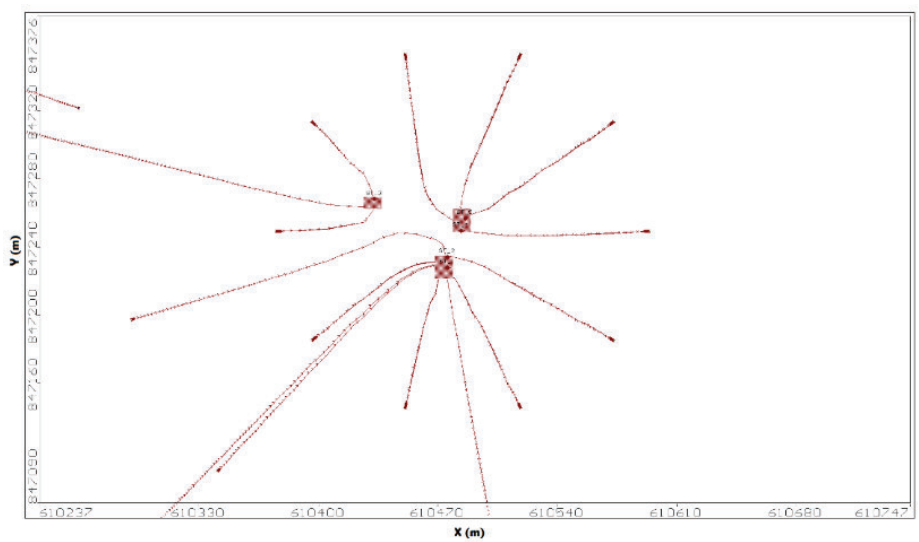

Figure 6. Pathines into the pumping wells with flowtime ticks 


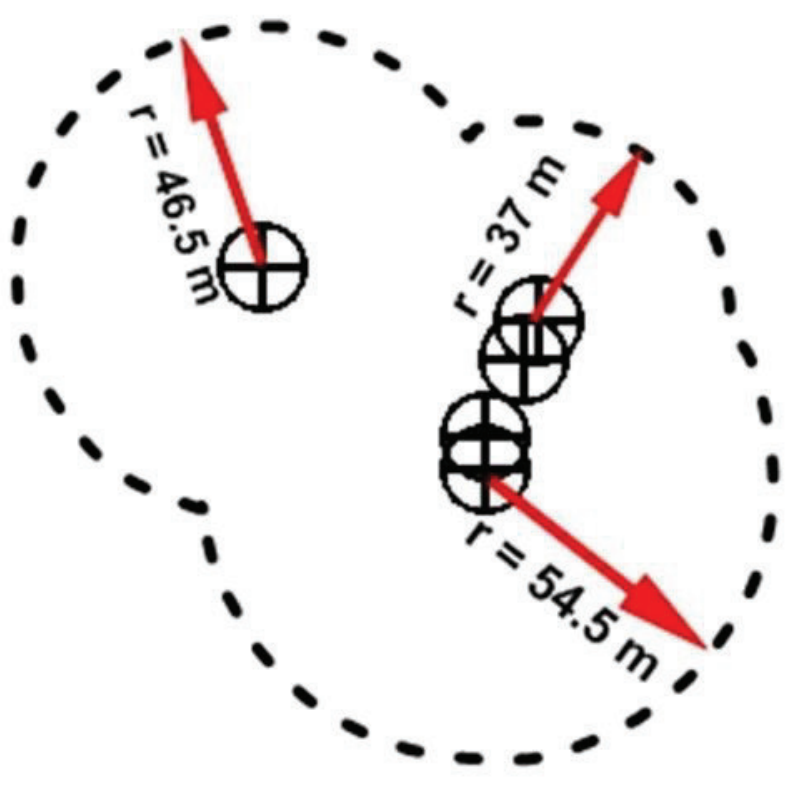

Figure 7. WHPA for drinking wells

Protecting the groundwater resource is a nonstop responsibility; challenging all water users. Notwithstanding groundwater usage for drinking aspects is increasing, awareness for WHPA is still not fully recognized. Numerical groundwater flow modeling combined with particle tracking codes is selected as the used delineation approach in this study. This method allows full interaction of hydrogeological, land-use, PCS, and different extraction rates in delineating the WHPA. The WHPA differs according to the pumping rates and groundwater flow direction. Nevertheless, the used approach allows to superimpose different WHPA for pumping wells to obtain final WHPA for the concerned area.

\section{Conclusion and recommendations}

Groundwater comprises of about $97 \%$ of global fresh water, allowing it to be an important, and sometimes the sole, source of drinking-water in many parts of the world. Sustainable Development Goal 6 calls to foster all efforts to ensure access to water and sanitation for all. Nevertheless, with groundwater providing nearly half the world population with drinking water, the responsibly of sustaining this resource is a priority to all. Pumping wells can sometimes, if not carefully protected, be an instant source of pollution to the groundwater. WHPA ensures the public health and protects the groundwater quality by applying restrictions and limitations on landuse activities within it. Many approaches are used for WHPAs delineation worldwide. In this study, numerical groundwater flow modeling with particle tracking codes were used, as this approach allows full interaction of hydrogeological, landuse, PCS, and different extraction rates in delineating the WHPA. The study area is a drinking water plant, located in Samadoun Village, Ashmoun City, Menofia Governorate. Data collection activities were performed including wells inventory, ground levels, lithology of wells, and hydrogeological data for groundwater aquifer. Nevertheless, the data collection activities also include inventory of PCSs, land-use, and availability of sanitary network. Three dimensions groundwater and solute transport model is built up using MODFLOW code and utilized to delineate the WHPA for the drinking wells. The study area belongs to the Nile Delta aquifer with thickness of Pleistocene deposits varies between $150-300 \mathrm{~m}$. Quaternary deposits is covering the study area by Holocene silty and clay deposits with a thickness vary between $10-15 \mathrm{~m}$. The ground surface is commonly flat; where the land surface has been prepared to provide a suitable surface for irrigation. The topography varies between 12 and 14 meters above mean sea level and underlain by Holocene sandy silt and clay. The average piezometric head varies between 10$12 \mathrm{~m}$ (above mean sea level). The groundwater flow direction is from the south to the north. The groundwater salinity is less than $500 \mathrm{ppm}$. The simulated area is $14 \mathrm{~km}^{2}$ with $4.4 \mathrm{~km}$ in the north-south direction and $3.3 \mathrm{~km}$ in the east-west direction. The grid is divided into three layers according to the different hydrogeological characteristics. Flow and transport boundary conditions were set to the model. The model was calibrated against the available groundwater heads and quality; and then run according to extraction rates to delineate the WHPA for the pumping wells used for drinking uses. The study used 50-day isochron horizontal travel distance for the three pumping wells. The WHPA radius was determined for the three wells and the radius ranges from $37 \mathrm{~m}$ to $54.5 \mathrm{~m}$. The final superimposed WPHA has to be protected from any sort of landuse.

The study recommends the enforcement of delineating WHPA for any drinking well through the numerical modeling coupled with particle tracking module, as it integrates all hydrogeological, landuse, and operation 
scenarios aspects. Nevertheless, awareness of the role and importance of WHPA has to be spread between all groundwater users. Moreover, monitoring of groundwater quality has to be regularly checked, to ensure the suitability of the water and its compliance to WMO guidelines.

\section{References}

Dressing, S. A., D. W. Meals, J. B. Harcum, J. Spooner, J. B. Stribling, R. P. Richards, C. J. Millard, S. A. Lanberg, and J. G. O’Donnell. "Monitoring and Evaluating Nonpoint Source Watershed Projects." Washington DC: United States Environmental Protection Agency, Office Of Water, Nonpoint Source Control Branch (2016).

Fadlelmawla, Amr A., and Mohamed A. Dawoud. "An approach for delineating drinking water wellhead protection areas at the Nile Delta, Egypt." Journal of environmental management 79, no. 2 (2006): 140-149.

Laws, Edward A. Aquatic pollution: an introductory text. John Wiley \& Sons, 2017.

Minnes, Sarah, and Hugh Simpson. "Capacity for source water protection in Ontario's privately-serviced rural areas." Geoforum 116 (2020): 12-23.

NGWA, 2017, Groundwater and Drinking water, NGWA information brief, http://www.ngwa.org/MediaCenter/briefs/Documents/Groundwater\%20and\%20Drinking\%20Water\%20web .pdf

Pollock, David W. User guide for MODPATH version 6: a particle tracking model for MODFLOW. US Department of the Interior, US Geological Survey, 2012.

RIGW, 1992, The Hydrogeological Map of Egypt, Nile Delta, scale of 1:500,000,

Smith, Mark, K. Cross, M. Paden, and P. Laban. "Spring-Managing groundwater sustainably." IUCN, Gland, Switzerland (2016).

Sousa, Marcelo R., Emil O. Frind, and David L. Rudolph. "An integrated approach for addressing uncertainty in the delineation of groundwater management areas." Journal of contaminant hydrology 148 (2013): 12-24.

U.S. Environmental Protection Agency (EPA), 1997. State source water assessment and protection programs guidance: final guidance. Office of Water, Report EPA-816-R-97-009.

US Environmental Protection Agency (EPA), 1987 Guidelines for delineation of wellhead protection areas. Office of water, Report EPA-4405-93-001

WHO, 2006, Protecting Groundwater for Health, Managing the Quality of Drinking-water sources. 